\title{
Customer Loyalty Programmes: The Loss To The Fiscus In South Africa
}

Teresa Calvert Pidduck, Monash University, South Africa Karen Odendaal, Monash University, South Africa

\begin{abstract}
The 2013 Budget Speech presented by the South African Minister of Finance highlighted that the best way to generate resources is to grow the economy and increase the tax base. In investigating the possible broadening of the South African tax base, as well as improving revenue administration, there is evidence of a gap in the taxation of customer loyalty programmes. The complexity of identifying and administering the receipt of customer loyalty award credits for millions of individuals has led to the receipt of customer loyalty award credits not being taxed whilst the expenses related to these award credits are being deducted by businesses. In closing this gap, the South African Revenue Service may be able to increase the tax base and limit fiscal leakage. For this reason, any gaps in the taxation of receipts and accruals is of interest to any researcher, taxpayer and government interested in understanding where current administration of legislation may be failing. In this study, the authors consider the tax leakage from a legislative and administrative perspective as well as investigate possible solutions. The revenue authorities in South Africa are urged to make changes to the current tax administration in order to prevent inconsistencies in treatment and tax leakage without negatively impacting the essence of the customer loyalty programmes.
\end{abstract}

Keywords: Award; Customer Loyalty Programme; Deduction; Income; Leakage; Revenue Administration; Revenue Reform; Tax Base

\section{INTRODUCTION}

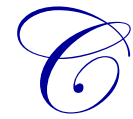

ustomer loyalty programmes (CLP's) have been used worldwide for more than five decades but have only recently entered the South African landscape (Trade Conferences International, 2013, p. 1). Despite the relative growth, CLP's in South Africa already generate R12 billion per annum with more than 10 million South Africans carrying at least one loyalty card (Trade Conferences International, 2013, p. 1). The increased use of CLP's has changed the nature of economic transactions occurring between businesses and customers in the South African landscape, without a corresponding change in how these transactions are dealt with at a fiscal level. One area of concern is how these transactions are dealt with by both the taxation legislation and the administration thereof. This study examines how taxpayers receiving customer loyalty award credits are not taxed on the receipt of these awards but businesses are able to deduct the costs associated with providing CLP awards.

The concern raised with regards to amendment of taxation legislation and administration is not restricted to South Africa and is in fact a worldwide concern. Globally, it is recognised that taxes are necessary to finance public spending and forms a non-inflationary way of ensuring that the burden of paying for such spending is fairly distributed (Bird, 2008, p. 2). However, tax policy is not just about economics and fiscal spending but it is also about justice and fairness (Bird, 2008, p. 2). This fairness cannot be achieved if the tax rules and regulations cannot keep pace with the rapidly changing economy, as this will increase economic distortions or simply become sidestepped by market innovations and technology to avoid its barriers (Cockfield, 2006, p. 138; Neubig \& Poddar, 2000, p. 1155). Fairness can also not be achieved where taxpayers react by re-arranging their affairs to minimise tax liabilities at the margin if policy is not amended (Rose, 1985, p. 315).

The global concern of not adapting tax policy to allow for changes in the economic environment, raises a major question regarding the ability of governments to adapt their tax systems to the new economy. The adaptation 
of the tax policy must be undertaken with the speed necessary to minimize adverse economic distortions from the blurring of the many tax boundaries (Neubig \& Poddar, 2000, p. 1153). In developing countries, such as South Africa, most fiscal experts propose tax reforms that broaden bases, lower tax rates and improve administration (Bird, 2008 , p. 2). Similarly, it has long been argued that income tax should be as broad as possible so that all incomes, no matter the source, should be treated as uniformly as possible such as suggested by the authors later in this article (Barreix \& Roca, 2007; Bird, 2008, p. 4; Broadway, 2005). For countries such as South Africa, where the reform of tax systems and of tax structures has become a necessary and daunting pursuit, the amendment of taxation policy must aim to achieve this fairness with the hope of achieving sustainable economic growth (Katz, 1996, p. 2). The investigation of new forms of revenue from sources relating to the changed nature of the economic landscape, such as CLP's, is thus crucial to increase the tax base whilst trying to maintain fairness within tax policy.

In light of the fact that CLP award credits are not currently being taxed, the legislation and administration in South Africa, specifically with regards to revenue collection needs to adapt to the changing economic environment. These changes should be performed so that the taxation of CLP transactions does not result in inconsistencies in the treatment of CLP income and expenditure. In not addressing this issue, the revenue authority in South Africa is effectively allowing these inconsistencies to drain the fiscus of much needed revenue and allow scope for tax leakage. The importance of limiting the scope for tax leakage in South Africa was highlighted by the South African Minister of Finance in his 2013 Budget Speech where he emphasised that various measures were proposed to combat this problem (National Treasury, 2013, p. 21).

Notwithstanding the above, it is recognised that in adapting legislation and administration, in an economic environment that is in a constant state of innovation and flux, any revenue authority would need to invest a significant amount of time and resources at the highest possible level (Calvert, 2012, p. 2). Such significant investment of resources forms a challenge in itself, particularly in the developing economies such as South Africa where specialist skills are often scarce. The struggle entered into by the revenue authority in South Africa to identify and combat tax leakage is thus a daunting task, but there may be adequate systems in place governing other forms of revenue collection and administration that may be used to fast-track tax collection on CLP award credits.

Besides numerous benefits surrounding CLP's, various studies indicate some instances of a certain amount of frustration or negativity associated with these programmes (Dowling \& Uncles, 1997, p. 81; Russell \& Julie, 2006, p. 459; Stauss, Schmidt \& Schoeler, 2005, p. 230). Therefore, by suggesting the implementation of tax on CLP award credits, it is crucial to understand why CLP's are used by businesses in order to ensure that the essence of such programmes are not undermined. The operation of CLP's can be described as programmes being implemented by entities to provide customers with incentives to buy their goods or use their services. If a customer supports a specific entity with buying their goods or services, the customer is rewarded by receiving awards credits which they can redeem for further free/discounted goods or services from the entity itself or third party entities (IFRS Foundation, 2011b, para. 1-2). Therefore, any taxation implications arising from such CLP's should not inhibit the benefits associated with CLP's for both the business and the customer.

\section{Research Purpose and Objectives}

Increasing the tax base in South Africa has been identified as an area of interest in light of existing budget deficits (National Treasury, 2013, p. 11). For this reason any gaps in the taxation implications related to CLP's is of interest to any researcher, taxpayer and government interested in understanding where current administration of legislation may be failing. The discord between the nature of CLP's and their corresponding taxation implications should be of concern to government, as tax policy within South Africa aims to limit the scope of any tax leakage. This study aims to provide insight into the tax leakage occurring as a result of this issue as well as possible solutions thereto. In this study, the authors consider the current tax implications of CLP's for the business and customer from a legislative perspective as well as an administrative perspective. In addition to this, the authors investigate possible solutions to the inconsistencies between CLP income and expenditure. 
The research objectives to be pursued in addressing the goal of the research can be formulated as follows:

- To identify the fiscal leakages occurring as a result of the introduction of CLP's in South Africa.

- $\quad$ To recommend a method of taxation of CLP award credits.

- To determine the financial impact of the recommendation in the financial services sector in South Africa.

\section{RESEARCH DESIGN \& METHODOLOGY}

The research paradigm for this study was qualitative and exploratory; in particular a multiple instrumental case study (Stake, 2005). The multiple case study design that was selected was not simply to describe the cases for description's sake but to see patterns, relationships and the dynamics of the tax implications of the customer loyalty award credit and thus focuses on different perspectives of one issue (Creswell, 2007, p. 74; Henning, Van Rensburg \& Smit, 2004, p. 32). In using this multiple case study design, the study used cases to make comparisons, build theory, or propose generalisations regarding the taxation of CLP's (Leedy \& Ormrod, 2005, p. 135). In order to illustrate the financial effect of the problem, the cases are investigated from a financial angle using data gathered from different sources, such as documentation and archival records, including the annual financial statements (Hesse-Biber \& Leavy, 2011, p. 265). The cases investigated form a microcosm of a larger system and that what is found there, is some larger symptomatic of what is going on more generally (Gomm, Hammersley \& Foster, 2000, 99).

\section{Sampling}

CLP's are widespread and are used by businesses as diverse as supermarkets, airlines, telecommunications operators, hotels and credit card providers (IFRS Foundation, 2011b, para. BC2). For the purposes of this study, only businesses within the financial sector that operate credit card based CLP's were identified. These businesses were selected from the Johannesburg Stock Exchange (JSE) top 40 Tradeable Index as provided by Reuters (Reuters, 2013). Companies were further selected in light of the ability of the researchers to obtain financial data related to their CLP's from their annual financial statements, therefore only those entities that report and disclose credit card based CLP's. Two companies were thus available for use within this study namely, FirstRand Limited (FirstRand) and Discovery Holdings Limited and its subsidiaries (Discovery). The selection of the two cases have been made in order to illustrate the taxation inconsistencies resulting from CLP's in the financial services sector in South Africa and thus suits the aim of the study.

\section{DISCUSSION}

The 2013 Budget Speech presented by the South African Minister of Finance highlighted that though South Africa's economy has continued to grow, this growth has occurred at a slower rate than projected in the 2012 Budget (National Treasury, 2013, p. 4). The slower rate of growth has been attributed, amongst others to the economic turbulence experienced in South Africa as a result of global economic uncertainty. In light of this, South Africa experiences a revenue shortfall of R16.3 billion which is estimated to be 5.2 per cent of GDP in 2012/13 (National Treasury, 2013, p. 9). In the Medium Term Budget Policy Statement (MTBPS) released in 2012, it was noted that "If the economic environment deteriorates, government will need to reconsider current expenditure and revenue growth plans. In a lower growth scenario, an appropriate balance between spending restraint and new revenue initiatives would be necessary" (National Treasury, 2012, p. 6). The effect of the slower economic growth rate experienced in South Africa results in the government needing to identify new revenue initiatives as suggested by the MTBPS in 2012. The Minister of Finance supports this presumption when noting that the best way to generate resources is to grow the economy and increase the tax base (National Treasury, 2013, p. 11). In the past, the increase in the tax base in South Africa has been made through policy reforms and improved revenue administration, but this is an ongoing process (National Treasury, 2013, p. 22). In investigating the possible broadening of the South African tax base as well as improving revenue administration there is evidence of a gap in the taxation of CLP's. In brief, the receipts of CLP award credits are not currently included in the income of taxpayers but costs associated with providing these award credits are deducted in determining the taxable income for businesses. 


\section{Accounting Treatment vs. Taxation Treatment}

In order for the authors to be able to analyse the selected cases, an understanding of the basic accounting guidance provided for CLP's, is necessary. Accounting requirements for CLP's are contained in IFRIC 13 and apply when an entity provides CLP award credits as part of revenue transactions. When an entity receives payment for providing goods or services, the entity receives the full consideration as advertised for those goods or services. In accounting for a CLP, IFRIC 13 requires that "some of the consideration received in respect of the initial sale should be allocated to the award credits and recognised as a liability until the entity fulfils its obligations to deliver award credits to the customer" (IFRS Foundation, 2011b, para. BC7). The consideration allocated to the award credits shall be measured by reference to their fair value taking into account, amongst others, the proportion of award credits that are not expected to be redeemed by customers (IFRS Foundation, 2011b, para. 6 and AG2). Once a customer redeems their award credits, the entity then satisfies its performance obligation of delivering the free/discounted good or service and should consequently recognise the revenue that that was initially deferred as a liability.

The International Financial Reporting Interpretation Committee (IFRIC) reached consensus that in a CLP, the customer is implicitly paying for the right to receive free/discounted goods or services in future (IFRS Foundation, 2011b, para. BC7(a)). For this reason, from a pure financial accounting perspective, the business providing the CLP, receives consideration for separately identifiable components of the initial transaction, i.e. the sale of the initial good/delivering of the initial service and a further performance obligation to supply free/discounted goods or services.

Notwithstanding the consensus reached by IFRIC, the tax implications resulting from receipt of award credits in a CLP transaction would not follow this treatment as taxation legislation forms its own country specific guidelines. The authors recognise that from a taxation perspective this becomes more complex, as a customer belonging to a loyalty programme would pay exactly the same amount for the initial good/service as any other customer not belonging to that loyalty programme and distinction between these two is necessary to combat tax leakage relating to the individual taxpayer belonging to the loyalty programme and receiving the free/discounted good or service.

\section{Taxation Implications}

The taxation legislation within South Africa imposes two kinds of tax, namely direct taxes which are levied on income and wealth of both individuals and companies, and indirect taxes which are levied on transactions or certain commodities. Direct taxation, as dealt with in the Income Tax Act no 58 of 1962 (the Act), addresses the tax implications relating to both income and expenditure. Within the Act, it is evident that where one taxpayer seeks to claim a deduction for expenditure paid to another, the latter will include the corresponding receipt into income. This can be illustrated by the following example:

\section{Example 1}

Company A employs taxpayer B within its organisation for an amount of R10 000 per month (R120 000 per annum). In terms of the legislation, provided that no exceptions apply, Company A would be allowed to deduct R120 000 in order to arrive at an amount of taxable income. Taxpayer B would, provided that no exceptions apply, include the R120 000 as income in calculating his/her taxable income.

The effect of such transactions would on the face of it, promote an equitable treatment of transactions for the fiscus. Therefore, where one taxpayer enjoys the benefit of a reduced taxable income due to a deduction, another suffers the burden of a higher taxable income due to higher earnings. The South African Revenue Service (SARS), who collects tax for government use, would then see the cumulative effect of the transaction from both perspectives and would tax each of the taxpayers accordingly. This principle, though evident in the above example, does not occur in CLP's in South Africa.

The problem identified does not stem from inadequate legislative requirements but from inadequate administrative processes within the manner in which different forms of income streams are identified. In order to 
illustrate the adequacy of the taxation legislation dealing with both income and deductions, a short discussion on each is included below.

\section{Gross Income}

The definition of gross income as defined in Section 1 of the Act is crucial in determining if the receipt of a customer loyalty award credit should be included in the income of a taxpayer. The gross income definition as included in the Act states the following:

"gross income" in relation to any year or period of assessment, means -

in the case of any resident, the total amount, in cash or otherwise, received by or accrued to or in favour of such resident...

during such a year or period of assessment, excluding receipts or accruals of a capital nature..."

(Income Tax Act No. 58 of 1962)

In determining if the receipt of customer loyalty rewards satisfies the provisions of the gross income definition each element should be considered individually.

\section{Total Amount in Cash or Otherwise}

The term 'total amount, in cash or otherwise' is not defined in the Act, we therefore look towards the courts to aid in interpretation thereof. Even without case law the phrase 'in cash or otherwise' indicates that gross income includes a receipt of an award that is not necessarily cash. It therefore appears as if award credits do meet the requirement to be included in a taxpayer's gross income. In addition to this analysis of the definition, case law corroborates the interpretation made by the authors as the term 'amount' includes receipts or accruals not only in the form of money but the value of every form of property earned, whether corporeal or incorporeal, which has a money value (De Koker \& Williams, 2013, para. 2.13; CIR v Butcher Bros (Pty) Ltd, 1944, p. 34; CIR v People's Stores (Walvis Bay) (Pty) Ltd, 1990, p. 21; WH Lategan v CIR, 1926, p. 20).

\section{$\underline{\text { Received By or Accrued To }}$}

Similar to the above, the words 'received by or accrued to' are not defined within the Act. The use of the disjunctive suggests that there are two ways in which income may arise; upon receipt of an amount or upon accrual of an amount. The courts have further clarified this and have held that the amount should be taxed upon the earlier of these dates (i.e. receipt or accrual) and may not be taxed twice ("Commissioner for Inland Revenue v Delfos," 1933, 94; De Koker \& Williams, 2013, para. 2.3).

In light of the above, the earning of award credits in terms of a CLP would constitute a receipt or accrual for purposes of gross income.

\section{$\underline{\text { Not of a Capital Nature }}$}

The distinction between capital or revenue receipts or accruals is fundamental in determining if CLP award credits meet the requirements of the gross income definition. This principle has again been interpreted by the courts and is explained as follows:

"If we take the economic meaning of "capital" and "income", the one excludes the other. "Income" is what "capital" produces, or is something in the nature of interest or fruit as opposed to principal or tree. This economic distinction is a useful guide in matters of income tax, but its application is very often a matter of great difficulty, for what is principal or tree in the hands of one man may be interest or fruit in the hands of another. Law books in the hands of a lawyer are a capital asset; in the hands of a book-seller they are a trade asset. A farm owned by a farmer 
is a capital asset; in the hands of a land jobber it becomes stock-in-trade." ("Commissioner for Inland Revenue v Visser," 1936, p. 276)

The receipt of CLP award credits is certainly not anything that produces further income and can therefore not be classified as capital in nature in terms of the gross income definition. Therefore, the receipt of such award credits constitutes gross income in the hands of the recipient.

\section{Deductions}

In order for an amount to qualify for deduction in the determination of a person's taxable income in South Africa, the requirements of the so-called 'general deductions formula' must be met, unless there is a specific provision in Section 11 of the Act relating to the type of expense incurred. The positive leg of the general deductions formula is contained in Section 11(a) and provides that in the determination of a person's taxable income from carrying on trade, these shall be allowed as a deduction from the income of such person so derived:

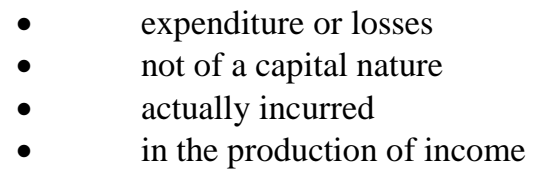

The negative leg of the general deductions formula is contained in Section 23(g) of the Act, prohibits the deductions of expenses or losses to the extent that such expenses or losses are not incurred for the purposes of trade. In determining if the costs associated with provision of CLP award credit satisfies the provisions of the general deduction formula each element should be considered.

Considering the first three elements in brief, the provision of CLP award credits often results in a financial outlay for the business providing such award credits. These financial outlays are currently being deducted by businesses in calculating their taxable income as they satisfy the requirements of the general deduction formula. This financial outlay is an expense, actually incurred for purposes of their trade (i.e. provided to customers) which is in the production of income. However, specific consideration is provided in determining if this expenditure is capital in nature as it may be argued that it provides an enduring benefit, similar to that of certain types of advertising expenditure.

In exploring this principle it is understood that advertising is ephemeral and consequently has to be a continuing process ("Commissioner for Inland Revenue v Pick 'n Pay Wholesalers (Pty) Ltd," 1987, p. 155). Therefore where this type of expenditure related to customer retention and attraction is incurred the expenditure would be deductible. CLP's of this nature are thus comparable to this form of advertising expenditure as they are also used as part of a continuing process employed by businesses in generating customer loyalty. In light of this, costs associated with the provision of CLP award credits of this nature meet the requirements of the general deduction formula and the principles outlined by the courts.

\section{Customer Loyalty Programmes in the Financial Services Sector}

Typically, the CLP's maintained in the financial services sector are those managed by credit card issuers. Under these CLP's, credit card holders earn awards credits for using their credit cards when making purchases. "The holders of these points typically can redeem them for items ranging from merchandise and gift cards from a variety of vendors to airline miles and hotel stays" (Cheng \& O'Connor, 2012, p. 372). From a practical perspective the financial institution receives a percentage of the total purchases made by the customer when using the financial institution's credit card at vendors. This percentage consideration is paid by the vendor to the financial institution, rather than directly from the customer that becomes entitled to the award credit (IFRS Foundation, 2011b, para. $\mathrm{BC} 4)$.

To understand the amounts disclosed within the annual financial statements (AFS) of each case, a brief description of the process employed by both FirstRand and Discovery, in deriving the financial impact of their CLP's, is provided below. 


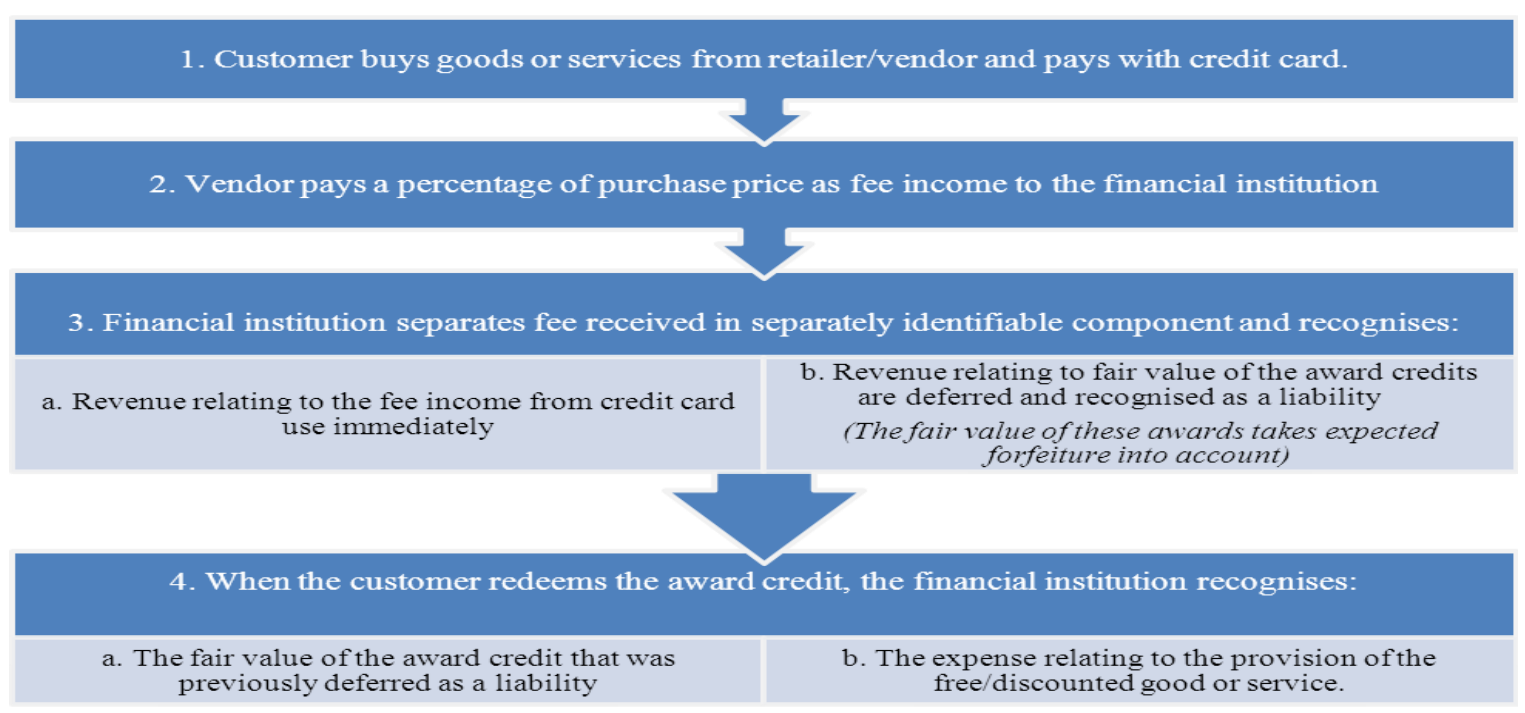

\section{Diagram 1}

Although IFRIC 13 is prescriptive in accounting for CLP's, it is not prescriptive in the disclosures required. However, International Accounting Standard (IAS) 18 requires an entity to disclose "the amount of each significant category of revenue recognised during the period" (IFRS Foundation, 2011a, para. 35). Due to the fact that the revenue relating to the redemption of award credits is in most instances seen as insignificant when compared to the other components of revenue, these amounts may not be separately disclosed.

\section{Implementing Tax on CLP Award Credits}

In determining how CLP award credits should be taxed it is important to consider the ability of the current administration to manage this new source of revenue collection. One factor that the authors have kept in mind in determining which option would be most effective and efficient, is the availability of resources that will need to be dedicated to drafting, testing and amending the tax legislation (Calvert, 2012, p. 1). Skills shortages experienced in South Africa must therefore be kept in mind before an onerous administrative process can be suggested as implementation of such systems may be doomed for failure. In addition to this, it is also important to maintain the integrity of CLP's, so that customers are not so severely impacted by any taxes levied that businesses choose to no longer provide CLP's. In essence the authors sought a solution to the method of taxing CLP award credits that has the following characteristics:

- The amendments necessary to legislation should not be so complex that it requires a significant investment of scarce resources, which would have the effect of delaying the implementation of a tax on CLP's.

- $\quad$ The resources required to administer the taxation of CLP award credits should not be so onerous that it delays implementation thereof.

- $\quad$ The tax and administrative burden on the customers receiving CLP award credits should be kept as low as possible in order to maintain the integrity of the CLP's. Managing customer perception in this regard is important in order to limit the impact of negative perceptions on the use of CLP's.

In light of these considerations, the authors determined that one possible option for the revenue authority in South Africa is to use an adapted version of one of the current types of taxation used in South Africa, namely a withholding tax (WHT).

\section{Withholding Tax}

In brief, the collection of a WHT by the revenue authority differs to that of other normal taxes because although the person to whom the income is paid or accrues is liable for the tax, the obligation to withhold the tax is 
imposed on the person who pays the amount (De Koker \& Williams, 2013, para. 14.19). A WHT can be described as a method of taxing non-residents, that relies upon connecting factors of which the referent is the income, not the person who earns it (De Koker \& Williams, 2013, para. 1.9). However, WHT's have most recently been applied to residents and non-residents in relation to dividend income at $15 \%$. In respect of implementing a WHT on the receipt of CLP award credits, this would mean that the entity providing the reward credit would withhold a percentage of the award credit (to be paid over to SARS) and only provide the customer with the net award credits remaining (after the WHT). Effectively upon completion of a tax return, individuals would then be exempt from including the CLP award credits from taxable income as WHT has already been levied upon this income.

The disadvantage of applying a WHT is the reduced rate at which WHT is normally levied, as WHT's are currently levied between $5 \%$ and $15 \%$. This is significantly different for taxes levied on natural persons, which is applied using a sliding scale between $18 \%-40 \%$ (Haupt, 2013, p. 5). The advantages and disadvantages of using WHT should thus be weighed by government in order to determine if the advantages compensate for a possible reduced rate.

\section{Advantages of Withholding Tax on CLP's}

One notable advantage of using a WHT is that all those receiving CLP award credits would be subject to WHT as opposed to only those persons registered for tax in South Africa (including non-residents). This would significantly increase the amount of WHT received, as whilst there were 13.7 million taxpayers in South Africa for the 2011/2012 fiscal year, only 3.3 million of these taxpayers paid 99\% of all income tax (SARS, 2012; Solidarity, 2013). This is significantly lower when compared to a total population of 51.7 million as at the 2011 census (Statistics South Africa, 2011).

The use of a WHT allows the revenue authority to tax CLP award credits using the same or similar resources that it currently employs in administering WHT and thus would require little additional resources when compared to introducing an entire new system. Further, the investment of scarce skills in developing legislation as well as related internal systems is also reduced when compared to that of a completely new tax. In addition to this, the benefits for both business and customers engaged in CLP's are also enhanced with the use of a WHT as opposed to a new tax. From the perspective of the customer receiving the award credits, the use of WHT would effectively eliminate onerous burdens on tax administration when completing their individual tax returns.

In the view of the authors, the largest benefit derived from using a WHT is that of perception management on the part of the customer. In explaining this benefit it is important to understand that customers are sensitive to costs, including taxes. The effect of this means that, the higher the tax burden, the less attractive CLP's are perceived by customers. A high rate of tax applied to CLP award credits would then result in customers not opting to enter into CLP's which would effectively undermine the essence of a CLP. Should a WHT be employed to tax CLP award credits, this problem would be significantly reduced as the customer would receive the award credits after the deduction of WHT has occurred. Customers would then not be required to pay additional tax upon submission of their tax returns and would thus not perceive the WHT as an additional tax burden. From the perspective of business, the imposition of a WHT would still allow the CLP to retain its integrity by attracting and retaining customers despite a slightly more onerous administrative burden.

\section{$\underline{\text { Implications for Business }}$}

Entities implementing a CLP will be required to adhere to more onerous payment and reporting requirements to SARS. This may increase the number of staff required to be invested in the CLP and customer relations departments within these businesses. Similarly, the financial department would be required to administer and pay the WHT to SARS at regular intervals, which may not coincide with the redemption of the CLP award credits by customers. Ultimately this would result in less favourable cash flow implication for the provider as the outlay of WHT would occur, in most instances, before the third party would be paid. Similarly, irrespective whether a customer redeems the CLP award credits, the business would still be liable to pay the WHT to SARS, adding a cash flow implication to the business where this would not occur in the current system. 
However, the administrative and cash flow burdens would not occur uniformly for all businesses, as only those businesses who operate CLP's would be required to adhere to this additional administration. The proportion of businesses thus affected would be minimal in comparison to the number of businesses operating in South Africa. Similarly, the administration would be significantly lower than that experienced by each individual belonging to a CLP had the administration burden been imposed upon them rather than the business. This would allow management within each business to determine if the benefits from the operation of a CLP would in fact outweigh the cost associated with the administration and cash flow implications.

It is the view of the authors that a WHT is, in its current form, the best mechanism to levy a tax on CLP's. The rate of this WHT should be levied at such a level that it does not become unattractive to those receiving the award credits or to the company's implementing the awards. In order to quantify the amount of additional revenue that may be received by government within the selected cases an example is illustrated below.

\section{Understanding the Numbers}

The financial implications of the process included in Diagram 1 are analysed by way of the following example:

\section{Example 2}

A credit card company provides a CLP operated by an e-commerce company. It grants customers one point (e-currency) for every R1 000 they spend at vendors with their credit card. Customers can redeem the points for any goods provided by the e-commerce company. In year one, customers of the credit card company buy goods with their credit card totalling R1million and therefore the credit card company grants 1000 points. The credit card company receives $3 \%$ of total purchases as fee income from the vendors. The credit card company estimates that the fair value of 1 point is R 1.00 and they pay the e-commerce company an amount of R0.90 for each point redeemed by its customers. The credit card company estimates that $80 \%$ of customers would redeem their points for future free/discounted goods or services. In year two, 600 points are redeemed by customers. Any outstanding points can be redeemed at any time in the future and do not expire.

With reference to Diagram 1 above the amounts are quantified below: 


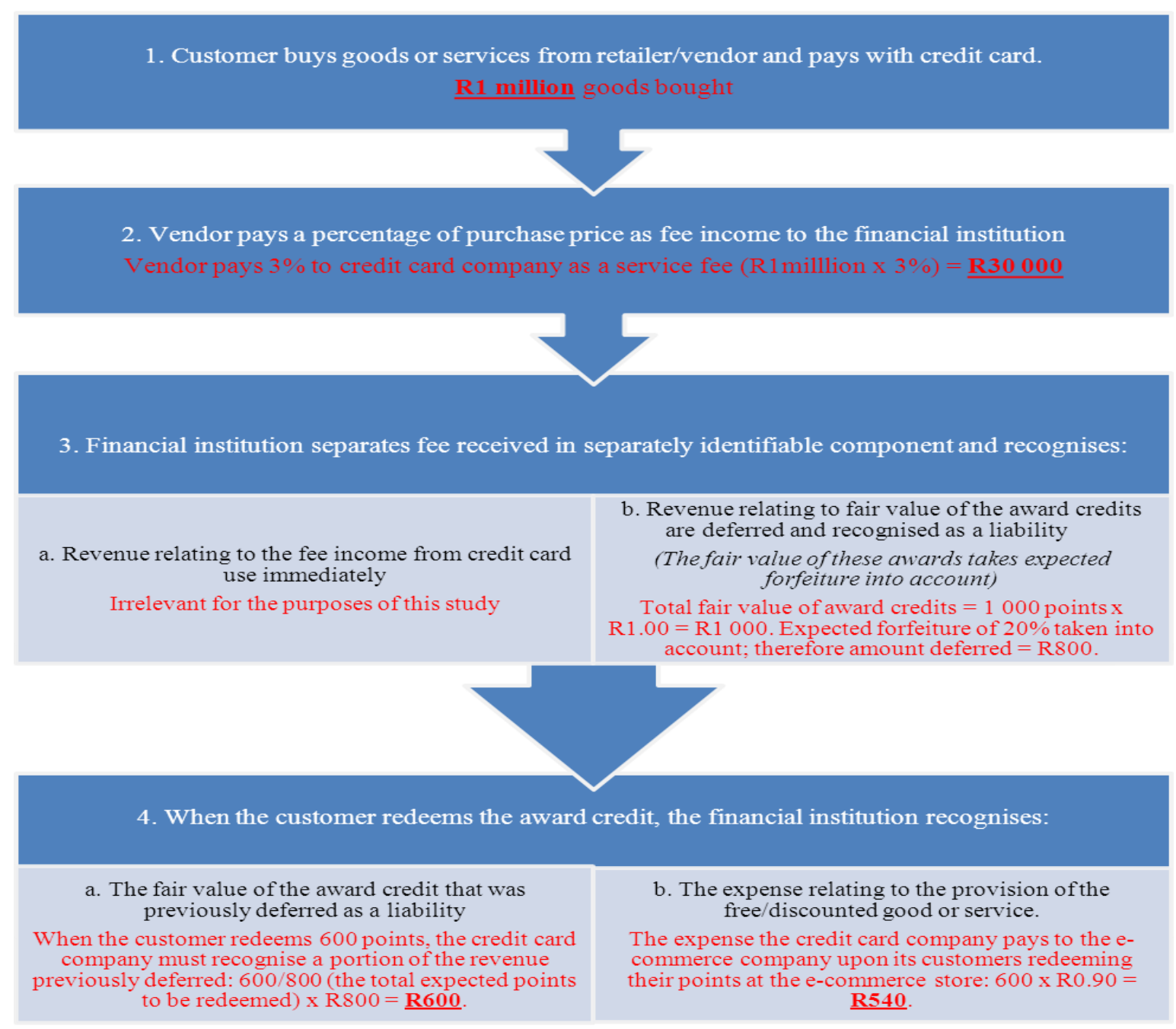

\section{Diagram 2}

Example 2 illustrates that many different amounts are used or calculated in accounting for CLP's. In understanding the amounts included within the case studies it is important to note that companies are not required to disclose all these detailed amounts. The authors have thus used what information has been disclosed in the AFS of the selected cases in quantifying the tax on CLP's below.

\section{Case Studies and Findings}

In implementing a WHT on CLP's the authors have quantified the additional revenue that may be generated for the revenue authority in South Africa from the selected cases below. The cases are analysed based on their 2012 financial results.

\section{Discovery}

The Discovery CLP operates similar to Example 2 and provides cash back when customers shop as well as a chance to earn Discovery Miles and boosting Pick 'n Pay smart shopper points (Discovery, 2013). In quantifying the amount that could be received from the taxation (via a WHT) of customers receiving Discovery's CLP award credits (Discovery Miles), the authors have extracted the following information from the Discovery AFS: 
- $\quad$ The total deferred revenue liability relating to the Discovery Miles benefit as at the end of the financial reporting period amounts to R104 million. This is the amount represented by $3 \mathrm{~b}$ in Diagram 2 above and includes all deferred revenue since the start of the Discovery CLP (Discovery Holdings Limited and its subsidiaries, 2012, p. 234).

- An amount for "Miles paid" which would represent the miles that were redeemed in the 2012 year and transferred from deferred revenue to revenue amounts to R62 million. This is the amount represented by 4.a in Diagram 2 above (Discovery Holdings Limited and its subsidiaries, 2012, p. 234).

As is evident from a review of the Discovery AFS, no amount is provided for the total fair value of award credits (Discovery Miles) granted. Therefore, the authors have based their WHT calculations on the amount of award credits redeemed in the 2012 year. In light of this, the amount of WHT to be collected by SARS if the WHT rate is set at 10\%, would amount to R6.2 million. This amount is significantly lower than the actual amount which would be collected by SARS as the amount which should be taxed would be the fair value of the award credits granted and not only those redeemed. Therefore, despite disregarding amounts used for expected forfeiture (represented by $3 \mathrm{~b}$ in Example 2) and only using awards redeemed (represented by $4 \mathrm{a}$ in Example 2) (rather than the total awards granted), SARS would collect R6.2million in WHT.

\section{FirstRand}

FirstRand also operates a CLP similar to that explained in Example 2 and provides customers with eBucks (electronic currency) when using their credit cards to make purchases (First National Bank, 2013). In quantifying the amount that could be received from the taxation (via a WHT) of customers receiving FirstRand's CLP award credits (eBucks), the authors have extracted the following information from the FirstRand AFS:

- $\quad$ The total deferred revenue liability amounted to R699 million as represented by 3.b in Diagram 2 above and includes all deferred revenue since the start of the FirstRand CLP (FirstRand Limited, 2012, p. 312).

- $\quad$ The expense relating to the provision of the CLP awards credits in the 2012 year amounted to R425 million as represented by 4.b. in Diagram 2 above (FirstRand Limited, 2012, p. 247).

As is evident from a review of the FirstRand AFS, no amount is provided for the total fair value of award credits (eBucks) granted. Therefore, the authors have based their WHT calculations on the amount paid to the ecommerce company upon customer award credit redemption. In light of this, the amount of WHT to be collected by SARS, if the WHT rate is set at $10 \%$, would amount to R42.5million. This amount is significantly lower than the actual amount which would be collected by SARS, as the amount which should be taxed would be the fair value of the award credits granted and not only the expense relating to those award credits redeemed. Therefore, despite disregarding amounts used for expected forfeiture (represented by $3 \mathrm{~b}$ in Example 2) and only using awards redeemed (represented by 4a in Example 2) whilst also disregarding the discounted price at which FirstRand pays the e-commerce company (represented by 4b in Example 2), SARS would collect R42.5million in WHT.

It is important to note that a third party supplies the award credits to the customer and FirstRand pays the third party for each award credit redeemed. FirstRand could measure the fair value of the award credits by reference to the amount it pays the third party, adding a reasonable profit margin (IFRS Foundation, 2011b, IFRIC 13, para AG13); however, it would be unreasonable for the authors to apply a profit percentage to the CLP expense of FirstRand as no indication of such a percentage is included in the AFS. If the authors were therefore to apply such a profit percentage, it would be arbitrary. Nonetheless, applying a WHT on the number of the expense indicates the minimum amount of loss to the fiscus relating to the award credits redeemed in 2012.

\section{Collated Findings}

In light of the amounts of WHT calculated for the two cases, it is evident that an immense amount of revenue is being lost by the fiscus as a result of not taxing the provision of CLP award credits to customers. The amounts calculated from Discovery and FirstRand equal R48.7million which is conservative in light of the fact that the authors have not made any adjustments as discussed above in respect of expected forfeiture (represented by $3 \mathrm{~b}$ in Example 2) and only using awards redeemed (represented by 4a in Example 2) as opposed to total awards granted. Additionally, in the case of FirstRand, no adjustment is made for the discounted price at which FirstRand pays the e- 
commerce company (represented by $4 \mathrm{~b}$ in Example 2). Therefore, if SARS had to apply WHT to the fair value of all award credits granted to customers, this amount would be significantly higher.

It is thus evident that the tax leakage occurring as a result of not taxing CLP award credits is resulting in a significant loss to the fiscus in South Africa.

\section{Limitations}

The following limitations of the study have been identified:

- The study is South African specific as it only addresses the tax implications in respect of CLP's in a South African context and thus provides limited use to other jurisdictions/countries.

- $\quad$ This study is limited to the normal tax implications arising from CLP transactions and thus excludes those related to other types of tax.

- $\quad$ The basis for the selection of the cases also causes a limitation to the study as only those entities using CLP rewards managed by third parties have been used as financial data related to other CLP's is limited.

- $\quad$ The study is limited to those CLP award credits supplied in the form of free/discounted goods or services by third parties and do not include CLP award credits provided to customers in the form of cash-back from Discovery and FirstRand (if any).

- $\quad$ To determine the pure impact on the fiscus, it would be necessary to obtain all information about the CLP's of the selected cases. As the authors do not have access to all the internal information from the selected companies, the authors had to make use of publicly available information, such as the published AFS and therefore could not make all adjustments as discussed above.

- As only two companies were used in a case study evaluation it is not possible to extrapolate the results of this study to all companies using CLPs in South Africa.

Notwithstanding the above, the authors believe the information obtained for purpose of quantifying the loss to the fiscus in not taxing CLP award credits, provides sufficient evidence to prove that the loss to the fiscus is significant.

\section{FUTURE RESEARCH}

In addition to the normal tax implications resulting from income and expenditure related to CLP's, it is also important to note that Value-Added Tax implications may also arise from the tax of these transactions. Future research will be required in this area in order to ensure consistency between the Income Tax Act and the ValueAdded Tax Act. This area of research will further impact the fiscus in the form of additional revenue from CLP transactions.

Future studies related to taxation of CLP award credits include an analysis of global trends in this area as well as well as tax implications resulting from other types of CLP's.

\section{CONCLUSIONS}

The complexity of identifying and administering rewards for millions of individuals has led to the receipts of CLP award credits not being taxed whilst the expenses related to these rewards are being deducted by businesses providing these rewards. The current legislation in South Africa already provides for the inclusion of these benefits into a taxpayers' gross income and the deduction of the related expenses in the hands of the provider. However, there is a gap in how these receipts may be included in a taxpayer's tax return. By using an existing administrative tool, SARS may easily adapt their systems with the use of a WHT. The financial impact on the fiscus for just one type of CLP used within two listed companies within the financial sector of the JSE Top 40, has led the authors to the conclusion that the loss to the fiscus in not taxing the receipt of CLP award credits is significant. The authors thus urge the South African Revenue Service to close this gap for fiscal leakage in order to prevent inconsistencies in the treatment if CLPs in South Africa. In doing so the intention of government to generate resources by increasing the tax base would be achieved in this area whilst providing government with a significant source of revenue with which to reduce revenue shortfalls. 


\section{AUTHOR INFORMATION}

Teresa Calvert Pidduck, B BusCom (Accounting), B Com (Accounting Honours), M Com Tax (Cum Laude), CA(SA). Her research interests include tax administration, tax avoidance, tax compliance and education. She is a lecturer in the Department of Accountancy Studies within the School of Business and Economics at Monash University South Africa and a guest lecturer at North West University (Potchefstroom campus). She has presented at various conferences and workshops on Taxation in South Africa and Australia. She is currently enrolled for her PhD at Rhodes University in Grahamstown, South Africa. E-mail: teresa.pidduck@ monash.edu (Corresponding author)

Karen Odendaal, B Com Accounting (Cum Laude), B Com Accounting Honours (Cum Laude), CA(SA). Her research interests include technical financial accounting matters including amongst others revenue recognition and fair value accounting, as well as research in the field of education, both in general and specific accounting education. She is a lecturer in the Department of Accountancy Studies within the School of Business and Economics at Monash University South Africa and a guest lecturer at the University of Kwa-Zulu Natal. She has presented at various conferences and workshops on Financial Accounting in South Africa and the United States of America. E-mail: karen.odendaal@monash.edu

\section{REFERENCES}

1. Barreix, A. \& Roca, J. (2007). Tax Policy in Developing Countries: Looking Back - and Forward. National Tax Journal, 61(2), 279-301.

2. Bird, R.M. (2008). The BBLR Approach to Tax Reform in Emerging Countries International Studies Program. Retrieved from http://isp-aysps.gsu.edu

3. Broadway, R.W. (2005). Income Tax Reform for a Globalised World: The case for a Dual Income Tax. Journal of Asian Economics 16.

4. Calvert, T. M. (2012, 17 January). The consequences of adapting tax legislation, using international standards in the developing worlds: A South African example. Paper presented at the Australasian Tax Teachers Association Conference, Sydney Australia.

5. Cheng, C. \& O'Connor, C. (2012). Accounting for Customer Loyalty Programs: Opportunities and Pitfalls. Tax Adviser, 43(6), 370-372.

6. Cockfield, A.J. (2006). The rise of the OECD as informal 'World Tax Organization' through national responses to e-commerce tax challenges. Yale Journals of Law and Technology, 8(1), 136-187.

7. Commissioner for Inland Revenue v Butcher Bros (Pty) Ltd, 13 SATC 21 (1944), Retrieved from LexisNexis South African Tax Cases Reports.

8. Commissioner for Inland Revenue v Delfos, 6 SATC 92(1933), Retrieved from LexisNexis South African Tax Cases Reports.

9. Commissioner for Inland Revenue v People's Stores (Walvis Bay) (Pty) Ltd, 52 SATC 9(1990), Retrieved from LexisNexis South African Tax Cases Reports.

10. Commissioner for Inland Revenue v Pick 'n Pay Wholesalers (Pty) Ltd, 49 SATC 132(1987), Retrieved from LexisNexis South African Tax Cases Reports.

11. Commissioner for Inland Revenue v Visser, 8 SATC 271 (1936), Retrieved from LexisNexis South African Tax Cases Reports.

12. Creswell, J. W. (2007). Qualitative inquiry \& research design: choosing among five approaches (Second ed.). London: Sage Publications.

13. De Koker, A. P. \& Williams, R. C. (2013). Silke on South African Income Tax

14. Discovery. (2013). Discovery Card. Retrieved 10 April 2013, from https://www.discovery.co.za/portal/individual/card

15. Discovery Holdings Limited and its subsidiaries. (2012). Annual Financial Statements. Available from https://www.discovery.co.za/discovery_coza/web/linked_content/pdfs/about_us/annual_financial_statemen ts_2012.pdf. (Accessed 22 March 2013).

16. Dowling, G. R. \& Uncles, M. (1997). Do customer loyalty programs really work? Sloan Management Review, 38(4), 71.

17. First National Bank. (2013). eBucks - the reward of choice. Retrieved 13 April 2013, from https://www.fnb.co.za/ebucks/what-is-ebucks.html 
18. FirstRand Limited. (2012). Annual Financial Statements. Available from http://www.firstrand.co.za/InvestorCentre/2012AnnualReportSections/FirstRand\%20Group\%20AFS.pdf. (Accessed 22 March 2013).

19. Gomm, R., Hammersley, M. \& Foster, P. (2000). Case study method: key issues, key texts. London: Sage Publications.

20. Haupt, P. (2013). Notes on South African Income Tax 2013 (Vol. 32nd edition). Republic of South Africa: $\mathrm{H} \& \mathrm{H}$ Publications, Hedron Tax Consulting and Publishing CC.

21. Henning, E., Van Rensburg, W. \& Smit, H. (2004). Finding your way in qualitative research. Pretoria: Van Schaik.

22. Hesse-Biber, S. N. \& Leavy, P. (2011). The practice of qualitative research (2nd ed ed.). Thousand Oaks, California: Sage Publications.

23. IFRS Foundation. IAS 18 Revenue (2011a), Retrieved from LexisNexis SAICA Handbook database.

24. IFRS Foundation. IFRIC 13 Customer Loyalty Programmes (2011b), Retrieved from LexisNexis SAICA Handbook database.

25. Katz, M. (1996). Third Interim Report of the Commission of Inquiry into Taxation. Available from https://www.google.co.za/url?sa=t\&rct=j\&q=\&esrc=s\&source=web\&cd=1\&ved=0CCoQFjAA\&url=http \% 3A\%2F\%2Fwww.gov.za\%2Fdocuments\%2Fdownload.php\%3Ff\%3D70508\&ei=7j6DUsvtFYjBhAels4Do AQ\&usg=AFQjCNHaoqi19FCv YcWAHWrWAQxzCU22w\&bvm=bv.56343320,d.ZG4. (Accessed 4 August 2010).

26. Leedy, P. D. \& Ormrod, J. E. (2005). Practical research: planning and design (8th ed.). New Jersey: Prentice Hall.

27. National Treasury. (2012). Medium Term budget Policy Statement 2012. Pretoria: Government Printer Retrieved from http://www.treasury.gov.za/documents/mtbps/2012/mtbps/MTBPS\%202012\%20Full\%20Document.pdf

28. National Treasury. (2013). 2013 Budget Speech. Pretoria: Government Printer Retrieved from http://www.info.gov.za/speeches/docs/2013/budget2013.pdf

29. Income Tax Act No. 58 of 1962, Government Printer.

30. Neubig, T. \& Poddar, S. (2000). Blurred tax boundaries: The new economy's implications for tax policy. Tax Notes, August 2000, 1153-1161.

31. Reuters. (2013). JSE Top 40 Tradeable Index. Retrieved 10 April, 2013, from http://in.reuters.com/finance/markets/index?symbol=za!J200\&sortBy=\&sortDir=\&pn=1

32. Rose, R. (1985). Maximizing Tax Revenue while Minimizing Political Costs. Journal of Public Policy, 5(3), 289-320.

33. Russell, Lacey \& Julie, Z. Sneath. (2006). Customer loyalty programs: are they fair to consumers? Journal of Consumer Marketing, 23(7), 458-464. doi: 10.1108/07363760610713000.

34. SARS. (2012). Media Statement by the Minister of Finance, Mr. Pravin Gordhan, on the Preliminary Outcome of Revenue Collection for the 2011/12 Fiscal Year. Retrieved 18 April 2013, from http://www.sars.gov.za/home.asp?PID=74731\&ToolID=2\&ItemID=76570

35. Solidarity. (2013). Actual number of taxpayers far lower than SARS professes it to be. Retrieved 18 April 2013, from http://solidariteit.co.za/en/actual-number-of-taxpayers-far-lower-than-sars-professes-it-to-besolidarity/

36. Stake, R. (2005). The Sage Handbook of qualitative research (3rd ed.). Thousand Oaks, California: Sage Publications.

37. Statistics South Africa. (2011). Census 2011 data supplied to National Treasury for local government equitable share formula. Retrieved 18 April 2013, from

http://www.statssa.gov.za/publications/Census\%202011 data supplied to National_Treasury.asp

38. Stauss, B., Schmidt, M. \& Schoeler, A. (2005). Customer frustration in loyalty programs. International Journal of Service Industry Management, 16(3), 229-252. doi: 10.1108/09564230510601387.

39. Trade Conferences International. (2013). Loyalty \& Rewards Conference. Retrieved 11 April, 2013, from http://www.tci-sa.co.za/brochures/lar_2013_brochure.pdf

40. WH Lategan v Commissioner for Inland Revenue, 2 SATC 16(1926), Retrieved from LexisNexis South African Tax Cases Reports. 